\title{
STAKHOLDER PERCEPTIONS ON THE PROSPECTS AND CHALLENGES OF PRACTISING CLIMATE - SMART AGROFORESTRY IN ASUNAFO NORTH MUNICIPAL ASSEMBLY, GHANA
}

Fatawu Abubakar Sadique ${ }^{1 *}$, Leslie Danquah ${ }^{2}$, Nana Yeboaa Opuni-Frimpong ${ }^{3}$

University of Energy and Natural Resources, Sunyani.

P. O. Box 214, Sunyani Ghana.

E-mail: sadiquefatawu@ rocketmail.com

${ }^{2}$ Department of Geographic Science,

School of Geosciences,

University of Energy and Natural Resources, Sunyani, Ghana.

E-mail: leslie.danquah@uenr.edu.gh

${ }^{3}$ Department of Forest Science,

School of Natural Resources,

University of Energy and Natural Resources, Sunyani, Ghana.

E-mail: nana.opuni-frimpong@uenr.edu.gh

* Corresponding author

E-mail: sadiquefatawu@ rocketmail.com 


\section{ABSTRACT}

This study assessed stakeholders' perception on the prospects and challenges of practising Climate-Smart Agroforestry in the Asunafo North Municipal Assembly in the Ahafo Region in Ghana. Interviewer administered questionnaires were used to collect cross-sectional data from 250 cocoa, food and cash crop farmers drawn from four (4) communities using simple random sampling. And nine (9) in-depth interviews were also conducted to elicit key stakeholder perspectives. Stakeholders also held the view that Climate-Smart Agroforestry encourages the use of stress-tolerant crop varieties, increase income, improve soil productivity, diversify farm produce, urges the reduction of input supply and recommends the timely usage of the inputs, ensures better market system for farm produce, cost of production decreases during the practice of Agroforestry, agro-ecological functions and Climate-Smart Agroforestry can best help adapt to the threats of climate change in the agriculture sector. The challenges included insecure tree ownership right, fast-declining soil fertility and long maturity period of Agroforestry trees, land tenure issues, illegal tree logging (chainsaw operators) on farms, lack of practical understanding of the approach, inadequate knowledge and information and inadequate supportive facilities in the study area. The study recommends further studies on the existing forest policy and legislations and its implications on the practice and adoption of Climate-Smart Agroforestry in respond to climate change in the area.

Keywords: Climate Change, Climate-Smart, Climate-Smart Agroforestry, Agriculture 


\subsection{INTRODUCTION}

Agroforestry system is an approach for climate change adaptation and mitigation, and very well embraced by ecologist and stakeholders in the cocoa industry due to its ability to increase cocoa yield while protecting the quality of the environment. Understanding the technique in practice will be geared towards gathering enough information to educate farming and policymakers to support the adaptations and formulate policies that support the development of the concept. On the prospects of CSAF, FAO (2014a) indicated that, CSA is geared towards increasing productivity while reducing the cost of production through efficient use of inputs and other resources to accomplish agriculture development by reducing the 'yield gap'. The 'yield gap' can decrease through the CSA approach by boosting the agroecosystems, improving efficacy of the soil, improving soil water management, quality livestock feed supply, reduce and efficiency inputs with higher returns to smallholder farmers geared towards poverty alleviation and increasing food security while reducing or removing agricultural GHGs in the atmosphere (FAO, 2014a). The agriculture production system of CSA needs to be increasingly sustainable with higher productivity of the soil and in case of crop yield (with high output-input ratio), must also reduce unnecessary use of external agricultural inputs such as inorganic fertilizers, use of agroecological process such as nutrient cycle and reduce practices that have adverse effects on the environmental and the ecological functions of the natural resources (Pretty et al., 2011). Cocoa Agroforestry has no negative impacts on cocoa productivity, this also enhance the adaptation and mitigation of climate change and being very beneficial to biodiversity conservation in Ghana (Blaser et al., 2018). Williams et al., (2015) explained the below as some of the opportunities in the methods of CSA in the SSA; CSA is the most effective poverty alleviation tool in Africa, sustainable increasing agricultural productivity through intensification in the SSA through agriculture adoption of best practices, water, soil and natural resources conservation geared towards 
intensification and climate change adaptation, CSA also serves as forest recovery base farming through Agriculture with prospects to the smallholder farmers not only through increasing the productivity but it also prevents the depletion of the natural resources, nontimber forest products and services functions, but the forest resources serve as sinks to the emitted GHGs and provides essential ecosystem functions. CSA offers alternative means of increasing productivity without the cultivation into new forest areas for purposes of increasing productivity and restores the ecosystem function through tree cropping on farmland (Williams et al., 2015). Moreover, Harvey et al., (2014) stated in the presence all the excellent prospects in the practices of CSAF, there are still factors that challenge the adoption of this approach that addresses the three climate-Smart goals. Williams et al., (2015) and Partey et al., (2018) indicated the below as significant challenges in the development of CSA approach; limited investment at all levels and high initial cost of investment in Africa, inadequate knowledge and understanding of the climate-smart agriculture approach, lack of data and an appropriate tools for analysis at both local and national front many African countries do not have long-term and landscape-level data and countries where some level of data exist, the data are in dispersed and not easily accessible, lack of a well-coordinated and supportive policy frameworks, existing policy framework and strategies prepared without the considerations of the need or demands for CSA and these policies may be incompatible CSA approach, lack of institutional arrangement for coordination and integration of CSA plans, farmer socioeconomic challenges at the farm level, lack supportive mechanism for women and youth, challenge of trade-offs between farmer and policymakers and lack of adequate financing mechanism to support the practice of CSA in the SSA. Some other challenges faced by the smallholder cocoa farmers which led to declining cocoa yield are due to variety of reasons including poor tree and soil management, pest and diseases, ageing tree stocks of cocoa, inadequate training and support and the underinvestment in maintenance, and the 
threat of climate change compounds this problem declining productivity in the cocoa sector by shrinking the area suitable for the cultivation (Läderach et al., 2011). The cultivation of cocoa is faced with several constraints such as losses due pests and disease, ageing cocoa farms and trees, limited yield potential of planting material and increasing temperature effects from climate change (Lahive et al., 2019). Sub-Sahara Africa is expected to suffer reduced agricultural productivity, increased water insecurity increased exposure to coastal flooding and extreme climatic events, and increased risks to human health. Africa is vulnerable to several climate-sensitive diseases and malnutrition for adults and children (Boko et al., 2007; Harrus and Baneth, 2005; Guernier et al., 2004). Agroforestry practices encountered constraints in Sub-Sahara Africa, which included land tenure issues, lack of social capital and improved germplasm and accession of recommended Agroforestry species (Partey et al., 2017). Williams et al., (2015) argued that in order to enhance the prospects of the CSA in the SSA, there is the need to promote the formulation and development of a supportive policy framework to create an enabling environment and the strengthening of the recommended bodies such as research institutions and the extension services to give smallholder alternative to select and adapt to the practices of Climate - Smart in their local perspective.

Stakeholders must know the benefits and cost from each of the agriculture systems or practices through demonstration and analysis when pursuing CSA goals. The stakeholders' role in promoting the practice of CSAF through shaping farmers' knowledge, building the capacities and provision of services to farmers. According Braimoh et al. (2016) identified six stakeholder groups at the centre of CSA adoption and development whose activities are closely linked together namely Producers, Policymakers and institutions, Extension workers, Consumers, Civil society, and the Private sectors. Partey et al. (2018), for CSA approach to be integrated into the mainstream agricultural policies and rural development plans, the policymakers would need a better understanding of the context-specificity of CSA towards 
win-win situation. Nyasimi et al., (2017) in a similar study in East Africa identifies Government institutions, Non-Governmental Organizations and Community Based Organization working in Agriculture sector are influential in the adoption of CSA when collaborating to disseminate information. Williams et al. (2015) makes the case that, the prevailing customary institution such as the traditional council affects farmers' accessibility to land and water resources; therefore, the traditional institution has a critical role geared towards promoting a secured agriculture system, water resources and land rights in SSA. Harvey et al., (2014) emphasized that, policy and institutional barriers, multiple policies and institutional barriers impede the integration, adaptation and mitigation goals within agricultural landscapes, systems that support conventional agriculture (with high use of fossil fuel and synthetic inputs) often prevail over those that support sustainable and climate-smart practices (Mattison and Norris 2005). In addition, development policy planning often is short - term (typically in 5-10-year cycles), whereas the integration, adaptation and mitigation goals require longer-term planning horizons (Biesbroek et al., 2009).

\subsection{RESEARCH METHODOLOGY}

\subsection{The study area}

The Municipality forms part of the new Ahafo Region with Goaso as the regional capital of the new Region (see Figure 1). The municipality is between latitudes $6^{0} 48^{\prime} \mathrm{N}$ and $7^{0} 00^{\prime}$ and Longitudes $2^{0} 31^{\prime} \mathrm{W}$, with a large land size of about 1093.77 sq. $\mathrm{Km}$ and 389.77 sq.Km of the land size covered by forest reserves. The Municipality's population was 124,685 during the 2010 population and housing census with the annual growth rate of $2.3 \%$. From the total population, $50.88 \%$ were females, and $49.12 \%$ being Males (ANMA, 2018). The population is youthful with most people under the age of 34 (GSS, 2010). The Municipality shares boundaries in the northeast Asutifi, Dormaa Municipality on the North-west and Juaboso Bia 
and Sefwi-Wiaso Districts on the West-South borders and the Asunafo South Municipality on the Southeastern.

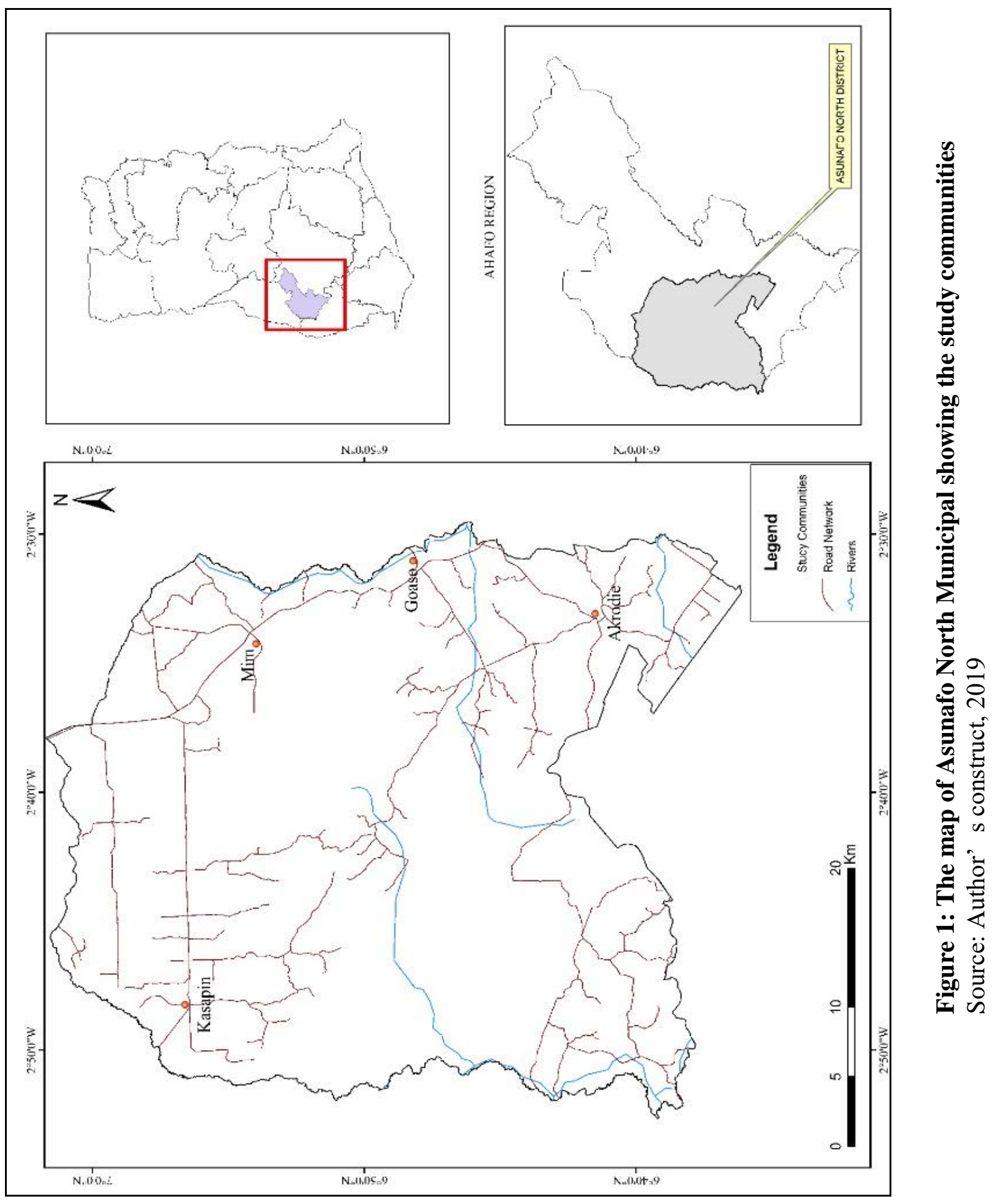




\subsection{Research design}

This research employed cross-sectional studies. Explorative and descriptive design from qualitative research was employed in this study. Qualitative approaches are used to give understanding to social realities just as is practised, experienced and explained by the respondents' themselves. Primary data was collected through cross-sectional survey research design among individual stakeholders in the Asunafo North Municipal. This study explores perceptions, knowledge, believes and culture dynamics, farming practices and experiences of stakeholders, the use of cross-sectional was more appropriate. Triangulation was used by merging the qualitative approaches and the quantitative approaches to collect data through indepth interview of key stakeholders to make sure the findings are reliable over time, and to improve the accuracy of the outcomes of the study.

\subsection{Units of analysis and observation}

The study involves individuals from the stakeholder groups in the practice of CSAF in the four cocoa-producing communities in the Asunafo North Municipal. Accordingly, the units of analysis encompasses different stakeholders at the center of climate smart development, with an emphasis on their perception on the prospects of practising Climate-Smart Agroforestry in the Asunafo North Municipal Assembly to achieve the triple-win of the CSA objectives set by the FAO, to assess the perceptions of the stakeholder groups on the prospects of practising CSAF. The units of observations are individual stakeholder groups in the field of CSAF adoption and development in the Asunafo North Municipal in Ghana.

\subsection{Sampling Strategy}

The four major cocoa-producing communities, which were synonymous to the four agricultural operation zones of the Asunafo North Municipal, are namely Goaso, Mim, Kasapin and Akrodie were purposively selected, based on the Municipal profile obtained 
from Ministry of Food and Agriculture (MoFA) as leading cocoa-producing communities in the Municipality. These fours operational zones are headed by four Municipality Development Officers (MDOs) who supervise the sixteen (16) Agricultural Extension Agents (AEAs officers) in the Municipality (ANMA, 2018). MoFA District office provided the study with the total number of registered food crop farmers and cash farmers, whereas the Cocoa health and extension division of the Ghana Cocoa Board (COCOBOD) District office provided the total numbers of registered cocoa farmers in the Municipal (Table 1). The number of registered farmers provided by the Cocoa health and extension division of the Ghana Cocoa Board and the District Agriculture office, MoFA provided the estimated total registered farmers in the Municipal (Table 1).

Table 1: Selected study communities with corresponding sample sizes

\begin{tabular}{lccccc}
\hline Communities & $\begin{array}{c}\text { Total cocoa } \\
\text { farmers }^{\mathrm{a}}\end{array}$ & $\begin{array}{c}\text { Total cash } \\
\text { crop } \\
\text { farmers }^{\mathrm{b}}\end{array}$ & $\begin{array}{c}\text { Total food } \\
\text { crop } \\
\text { farmers }^{\mathrm{b}}\end{array}$ & $\begin{array}{c}\text { Total } \\
\text { farmer in } \\
\text { ANM }\end{array}$ & $\begin{array}{c}\text { Number of } \\
\text { respondents } \\
(\%)\end{array}$ \\
\hline Goaso & 3950 & 464 & 4995 & 9409 & $55(22.06)$ \\
Mim & 4249 & 615 & 5090 & 9954 & $58(23.34)$ \\
Kasapin & 4582 & 839 & 6243 & 11664 & $69(27.34)$ \\
Akrodie & 4259 & 825 & 6545 & 11629 & $68(27.26)$ \\
Total & 17040 & 2743 & 22873 & 42656 & $250(100)$ \\
\hline
\end{tabular}

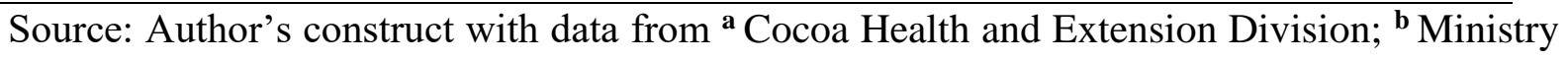
of Food and Agriculture, (ANM), 2019

\subsection{Sampling technique and size}

The study population comprised farmers in the four study communities. Farmers were grouped into three categories/strata namely; cocoa, food crop and cash crop farmers. A list of eligible farmers was generated from farmer data provided by the Ministry of Food and Agriculture and Cocoa health and extension division in the Asunafo North Municipality (Table 1). From the list, the total number of eligible farmers was estimated at 42,656 . The sampling formula by Kothari (2004) was used in the determination of the sample size for this study as shows below: 


$$
n=\frac{p q z^{2}}{E^{2}}
$$

Where, $n$ is the sample size, $z$ is confidence level $(\alpha=0.05)$, p was the proportion of the population of interest, farmers in the study area. Variable $q$ was the weighting variable and it was calculated as $(1-p)$ and $\mathrm{E}$ was a suitable error (level of precision). $p$ was 0.5 since statistically, a proportion of 0.5 result is adequate and dependable size predominantly when the population proportion is not known with certainty. This led to $q$ of 0.5 (1- 0.5$)$. Kothari (2004) suggests an error of less than $10 \%$ is usually suitable. Hence, an error of 0.05 was used to estimate a sample size of 250 respondents, representing $0.59 \%$ of the total eligible population for the purpose of this study. However, this exceeded the recommended sample size range of 80 - 120 respondents for socio-economic research works in Sub-Sahara African (Matata et al., 2001). Simple proportion was used to distribute the number of farmers needed per community. Thereafter, simple random sampling was used to select the number of farmers estimated for each community (Table 2).

Table 2: Sampling size estimates

\begin{tabular}{lccc}
\hline Communities & $\begin{array}{c}\text { Sample size of } \\
\text { Cocoa farmers }\end{array}$ & $\begin{array}{c}\text { Sample size of } \\
\text { Cash crop farmer }\end{array}$ & $\begin{array}{c}\text { Sample size of } \\
\text { Food crop farmers }\end{array}$ \\
\hline Goaso & 23 & 3 & 29 \\
Mim & 25 & 4 & 30 \\
Kasapin & 27 & 5 & 36 \\
Akrodie & 25 & 5 & 38 \\
Total & 100 & 17 & 133 \\
\hline
\end{tabular}

Source: Author's construct, 2019

\subsection{Primary data}

\subsubsection{Survey}

The survey is the most common quantitative data collection method that allows obtaining information about a given phenomenon, through questionnaires that reflect the opinions, perceptions, and behaviour of a group of persons (Almeida et al., 2017). This research 
administered semi-structured questionnaires which was the primary tool for data collection. The instrument was used to collect data on respondents ranging from their demographic characteristics, household information, farmers knowledge and practices of CSAF, factors that hinder the exercise of CSAF among others. Although all the questions in the semistructured questionnaires are set in the English language, the local language Twi was used as a communication medium during the data collection.

\subsubsection{Stakeholder in-depth interview}

The criterion-based, purposive sampling technique was employed for the choice of crucial stakeholder in the cocoa-producing communities; this was geared towards obtaining firsthand information from these institutional heads/stakeholders in the Asunafo North Municipality on the prospects of Climate - Smart Agroforestry (Table 3.4). Braimoh et al. (2016) identified six stakeholder groups at the center of CSA development and assessment, namely Producers, Policymakers and institutions, Extension workers, Consumers, Civil society, and the Private sectors. Data from critical key stakeholders was collected using structured and semistructured to assess their perceptions on the prospects of practising Climate-Smart Agroforestry. 
Table 3: Stakeholders and their role to the practice of CSAF

\begin{tabular}{|c|c|c|c|c|}
\hline $\begin{array}{l}\text { Stakeholder } \\
\text { Groups }\end{array}$ & Individual stakeholders & Sex & Number & Role \\
\hline \multirow[t]{3}{*}{$\begin{array}{l}\text { Policy Makers } \\
\text { \& Institutions }\end{array}$} & $\begin{array}{l}\text { 1. Municipal Chief } \\
\text { Executive, ANMA }\end{array}$ & Male & 1 & $\begin{array}{l}\text { Head of the Municipal } \\
\text { Assembly, } \\
\text { implementing central } \\
\text { government policies }\end{array}$ \\
\hline & $\begin{array}{l}\text { 2. Presiding Member, } \\
\text { ANMA }\end{array}$ & Male & 1 & $\begin{array}{l}\text { Presiding over } \\
\text { Assembly meetings, } \\
\text { Bye-laws and policy } \\
\text { implementations }\end{array}$ \\
\hline & $\begin{array}{l}\text { 3. Abusuapanin (head of the } \\
\text { royal family), Goaso } \\
\text { Traditional Council, ANM }\end{array}$ & Male & 1 & $\begin{array}{l}\text { Leasing land for } \\
\text { farming, addressing } \\
\text { land tenure disputes, } \\
\text { norms, taboos }\end{array}$ \\
\hline \multirow[t]{3}{*}{$\begin{array}{l}\text { Extension } \\
\text { workers }\end{array}$} & $\begin{array}{l}\text { 1. Agricultural Extension } \\
\text { Officer-MoFA, ANM }\end{array}$ & Female & 1 & $\begin{array}{l}\text { Sensitising and } \\
\text { providing technical } \\
\text { services to farmers }\end{array}$ \\
\hline & $\begin{array}{l}\text { 2. District extension } \\
\text { coordinator - Cocoa health } \\
\text { extension division, ANM }\end{array}$ & Male & 1 & $\begin{array}{l}\text { Educating and } \\
\text { providing technical } \\
\text { assistance to cocoa } \\
\text { farmers }\end{array}$ \\
\hline & $\begin{array}{l}\text { 3. Assistant District Manager } \\
\text { - Forest Service Division, } \\
\text { ANM }\end{array}$ & Male & 1 & $\begin{array}{l}\text { Conserving forest } \\
\text { resources. Engage in } \\
\text { Afforestation and } \\
\text { reforestation }\end{array}$ \\
\hline $\begin{array}{l}\text { Farmer based } \\
\text { organisation }\end{array}$ & $\begin{array}{l}\text { Acting Vice President - } \\
\text { Akrodie Farmers' } \\
\text { Association, ANM }\end{array}$ & Male & 1 & $\begin{array}{l}\text { Advocacy and } \\
\text { educating farmers on } \\
\text { best practices }\end{array}$ \\
\hline Private sector & $\begin{array}{l}\text { Branch Manager - Samlen } \\
\text { Commercial Agency, ANM }\end{array}$ & Male & 1 & $\begin{array}{l}\text { Consulting and selling } \\
\text { of agrochemicals and } \\
\text { other inputs }\end{array}$ \\
\hline Producers & $\begin{array}{l}\text { Farmers \& consumers } \\
\text { (Goaso, Mim, Kasapin and } \\
\text { Akrodie) }\end{array}$ & Both & 250 & $\begin{array}{l}\text { Crop producers and } \\
\text { consumers }\end{array}$ \\
\hline
\end{tabular}




\subsection{Data collection}

The data was collected using a mixed-methods, which involves qualitative and quantitative methods. The data collection instruments included structured and semi-structured questionnaires. The structured and semi-structured questionnaires method of data collection is designed to get and compare responses from all respondents in the research work (Almeida et al., 2017). Interviewer-administered questionnaire was employed to collect quantitative and qualitative data among farmers who are the respondents of this research. Qualitative data was collected using interviewer administered questionnaires to farmers, and the other critical stakeholders' perception of the prospects and challenges of practising CSAF in the cocoaproducing communities, among others were obtained through self-administered semistructured questionnaires to help with the analysis. Farmers' perception and practice of Climate-Smart Agroforestry were determined through the use of semi-structured questionnaires administered by the interviewers on the field.

The stakeholders' perception of the prospects and challenges of CSAF in the cocoaproducing communities, among others were obtained through semi-structured questionnaires to help with the analysis. Data was collected from the vital developmental stakeholders (individuals) who are heads of various institutions in the Municipality that includes; the Assistant District Manager for Forest Service Division of Ghana Forestry Commission, Abusuapanin (head of the royal family) for Goase Traditional Council in Goaso, Branch Manager for Samlen Commerical Agency, District Extension Cordinator for Cocoa Health and Extension Division of Ghana Cocoa Board, Extension Ministry Food and Agriculture, Minicipal Chief Executive and Presiding Member for Asunafo North Municipal Assembly, Acting Vice President for Akrodie Farmers Association in Akrodie and the farmers from the study communities in Asunafo North Municipal. The data of the in-depth interview with key stakeholders in the Asunafo North Municipal was collected through the use of structured and 
semi-structured questionnaires (self-administered), geared towards assessing the stakeholders' perception on the prospects and challenges of practising Climate-Smart Agroforestry. A total of three weeks (21 days) were used for collection of the primary data including in-depth stakeholder interviews. In-depth interview (self-Administered) and Interviewer Administered Questionnaires were used to collect data type (selected) including respondents perception on the diversification of the farm produce, market security, cost of production, reduce input usage, efficient input usage, Agro-ecological functions of Agroforestry, soil and water improvement, shade and significance of AF to improvement of fertility.

\subsection{Data analysis and interpretations}

The raw data collected for the study using the questionnaires were processed, analysed and interpreted using Statistical Package for Social Science (SPSS v. 21) software into descriptive statistics to generate frequency distribution tables, cross-tabulation and graphs to give a pictorial understanding of presentations of data. This study employed predetermined themes using Microsoft Excel to group qualitative data into themes to answer research questions. Descriptive analysis, thematic and stakeholder analysis were adopted as the data analysis tools to give in-depth understanding of the data collected and analysed to answer the question.

\subsection{Ethical considerations}

The research started with a reconnaissance survey to the study communities during which the researcher interacted with community leaders (traditional authorities, Cocoa chiefs), Municipal authorities, the staff of the Cocoa Health and Extension Service of the Ghana Cocoa Board (COCOBOD) and Ministry of Food and Agriculture (MoFA) to inform them of the research and asked permission for the field. There was an oral agreement with 
respondents due to the possible low literacy rate. The interviewers informed each participant that their data and information were confidential, and give details on the topic and the purpose of the research to participants before the start of data collection. However, respondents have the right to back out of the agreement as and when they wished to since it was voluntary. Key stakeholders were informed of how significant their contributions would be for the development of Climate-Smart Agroforestry and their data and information was for academic purposes only.

\subsection{RESULTS AND DISCUSSIONS}

In identifying the perception of the stakeholders on the prospects of pracising CSAF in the area, this chapter focuses on the perception of various stakeholders on the prospects and challenges of CSAF; section 3.1 presents the producers and consumers perception on the prospects of CSAF, Policymakers and traditional institution perceptions on the prospects of CSAF (section 3.2), Extension workers perceptions on the prospects of CSAF (section 3.3), whereas section 3.4 presents the Farmer-based organisation and Private sector's perception of the prospects of CSAF in the area. This is geared towards understanding the perceptions of the key stakeholders on the prospects of practising CSAF in the Asunafo North Municipality.

\subsection{Producers and consumers perception on the prospects of CSAF}

The prospects of Climate-Smart Agroforestry was explored among farmers who are producers and consumers. This finding may help us to understand the perceptions of farmers on CSAF as intervention for climate change in the Agriculture sector. The result of the field study shows, $238(95.2 \%)$ respondents mentioned that agroforestry best helps adapt to the impacts of climate change and $12(4.8 \%)$ respondents stated that Agroforestry does not help to adapt to the impacts of climate changes (Figure 6.1). This finding is similar to Ashley (2015) that, the practice of Agroforestry system is frequently geared towards adaptation and 
mitigation of climate change. To clarify, Toppo and Raj (2018) asserted that the tree component of agroforestry has the potential to mitigate the effects of climate change such as drought, flood, prevents deforestation and restore soil quality. Therefore, it increases agriculture food production and provides alternative source of nutrition and income.

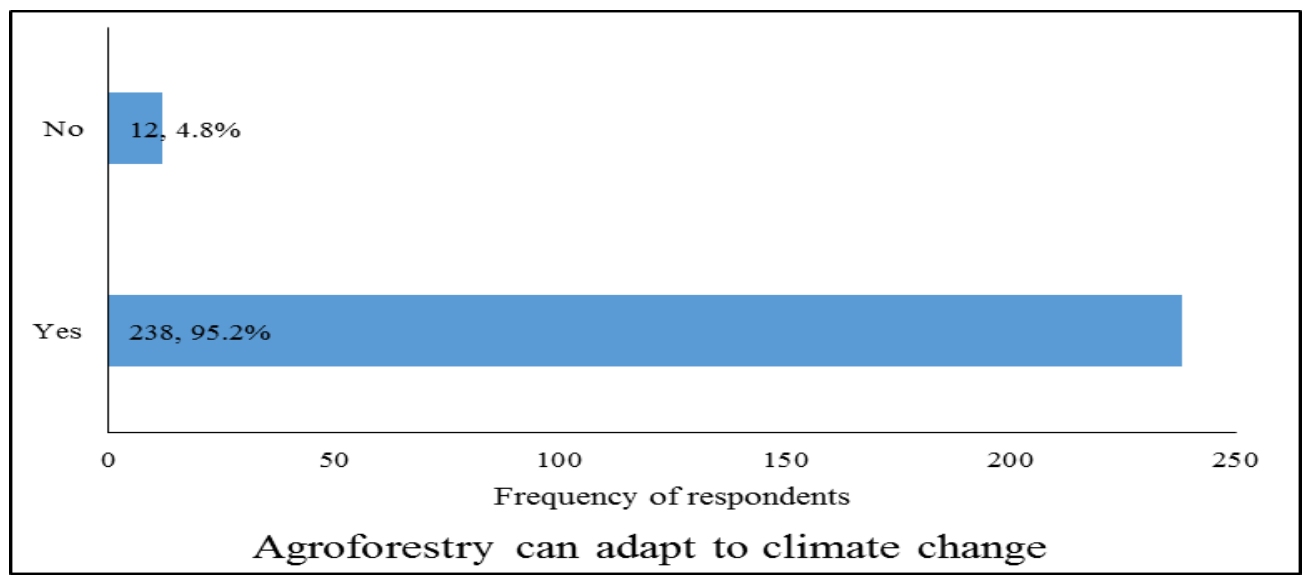

Figure 1: The use of Agroforestry to adapt climate change

Source: Author's field study, 2019

In identifying other potentials of Agroforestry as Climate - Smart Agriculture Technology, respondents were to indicate why they would plant Agroforestry trees on their farmland. As shows in Figure 6.2, $10(4 \%)$ respondents mentioned the ability of the tree component to sequester carbon, $98(39.2 \%)$ respondents said the agro-ecological functions of the tree component and another $98(39.2 \%)$ respondents said that planting trees on the farmland would serve as windbreak whereas $44(17.6 \%)$ respondents indicated the potential of the trees to provide shade to crops. Some of the issues emerging from this finding relate specifically to the potentials of trees to serves as 'nutrient pumps' while serving as a windbreak to crops on farmlands. Equally, Pretty et al. (2011) affirms this finding that trees are used for their agroecological process such as nutrient cycle that reduces the adverse effects of climate change on the environment and improves the ecological functions of the natural resources. 


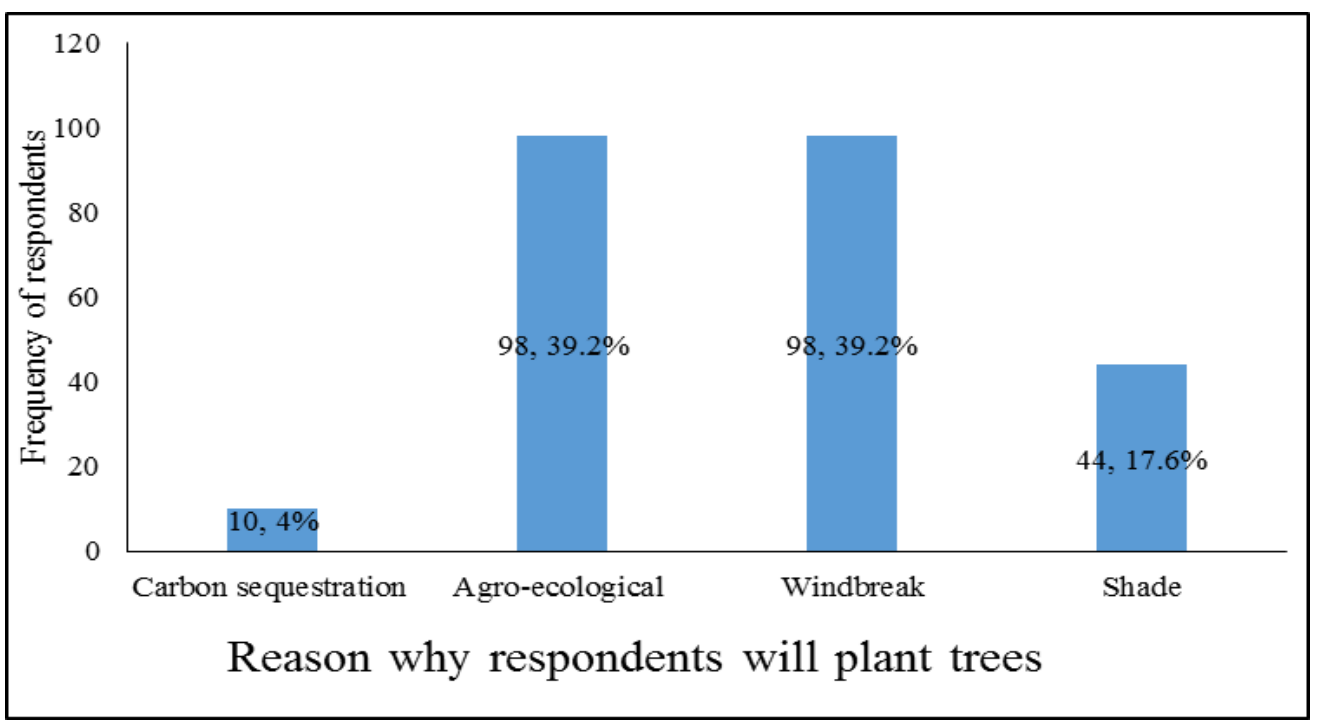

\section{Figure 2: The reason why respondents will plant trees on their farms}

Source: Author's field study, 2019

The prospect of the Agroforestry as Climate-Smart Agriculture Technology in ensuring market security of the farm products towards enhancing the resilience of the farming system was also investigated. The result of the field study presents, 196 (78.4\%) respondents mentioned that Climate-Smart Agroforestry ensures a better market system for farm produce. However, 54 (21.6\%) respondents indicated that Climate-Smart Agroforestry does no ensure market system for farm produce. An implication of this finding is the possibility that the Climate-Smart Agroforestry provides a better market system through the transaction of the different farm produce and this could boost farmer's decision to practice Climate-Smart Agroforestry. Conversely, it is possible to see how Hauswirth et al. (2012) agrees with Stringer et al. (2012) that market insecurity among others are known to affect the effective adoption of sustainable agricultural practice and makes it very difficult for smallholders to adopt sustainable agriculture practices.

The study evaluated the prospects of Climate - Smart Agriculture on the cost of production during the practice of Agroforestry. Table 6.1 presents the result of the field study, 58 (23.2\%) respondents mentioned that the cost of production increased during the practice of 
Agroforestry, 32 (12.8\%) respondents indicated that the cost of production remained the same during the practice of Agroforestry, $22(8.8 \%)$ respondents were not sure of the cost of production during the practices of Agroforestry and 138 (55.2\%) respondents mentioned that the cost of production decreased during the practice of Agroforestry. It can, therefore, be assumed that cost of production decreases during the practice of Agroforestry. Similarly, Kiptot and Franzel (2011) argued that Agroforestry technology is an operatively cost lessening agriculture approach that improves soil fertility and increases crop yield. Nevertheless, the FAO (2014) urges that Climate-Smart Agriculture is geared towards increasing productivity while reducing the cost of production through efficient use of inputs and other resources to accomplish agriculture development by lowering the 'yield gap'.

Table 4: The cost of production during the practice of Agroforestry

\begin{tabular}{lcc}
\hline Cost of production & Frequency & Percentage \\
\hline Increasing & 58 & 23.2 \\
Same & 32 & 12.8 \\
Not sure & 22 & 8.8 \\
Decreasing & 138 & 55.2 \\
Total & 250 & 100.0 \\
\hline
\end{tabular}

Source: Author's field study, 2019

\subsection{Policymakers and traditional institution perceptions on the prospects of CSAF}

According to Partey et al. (2018), for CSA approach to be integrated into the mainstream agricultural policies and rural development plans, the policymakers would need a better understanding of the context-specificity of CSA towards win-win situation. Nyasimi et al. (2017) in a similar study in East Africa identifies Government institutions, NonGovernmental Organizations and Community Based Organization working in Agriculture sector are influential in the adoption of CSA when collaborating to disseminate information. The various stakeholders mentioned their institutional role in promoting Agroforestry as Climate-Smart Agroforestry; the Municipal Chief Executive liaises with the Forestry Commission to apprehend and prosecute illegal loggers, and implements policies from the 
central government geared towards the sustainability of the farming system (Table 6.2) and also encouraged farmers to practice Climate-Smart Agroforestry; the Presiding Member of the Municipal assembly facilitates access to farm inputs for farmers and other technical assistance from institutions such as MoFA; and the Abusuapanin (the head of the royal family) of the Goase traditional Council promotes Agroforestry through the leasing of lands for practising Agroforestry, encourages other landowners to do same to ensure environmental sustainability. The traditional council also addresses disputes resulting from land tenures systems between farmers and landowners (Table 6.2). Williams et al. (2015) make a similar case that, the prevailing customary institution such as the traditional council affects farmers' accessibility to land and water resources; therefore, the traditional institution has a critical role geared towards promoting a secured agriculture system, water resources and land rights in SSA. The Municipal Chief Executive, Presiding Members and the Abusuapanin (Goaso traditional council) were interviewed to explore the prospects of Climate-Smart Agroforestry in the area policy and traditional institution which are mandated to making and implementing policies or bye-laws in the Asunafo North Municipality. The majority of the stakeholders reveal that, the practice of Agroforestry has positive relations to the farmer's socioeconomic development, this result is consistent with Nair (1993), with benefits such as agroecological functions, soil water improvement and the soil nutrient management as similarly indicated by Schaller et al. (2017) which are significant to the farmland geared towards increasing the productivity and income of the farmer, and CS Agroforestry intensifies diversification of farm products to manage risk and enhance the resilience of the farming system which also corroborates with Mbow et al. (2014).

The Municipal Chief Executive indicated that, agroforestry has the potential to ensure sustainability in the farming system through production of timber, these findings are consistent with Schaller et al. (2017) while preventing desertification. However, the concept 
is challenged with the activities of illegal loggers and inadequate knowledge. However, Hauswirth et al. (2012) suggested that institutions should provide appropriate technical, administrative and other support to an integrated process to develop and manage the process. The male Municipal Chief Executive with two (2) years' experience at ANMA indicated (2019);

"Illegal logging is a challenge in the practice of Agroforestry. However,

I am liaising with the forestry commission to apprehend and prosecute

illegal loggers and encourage farmers to practice Climate-Smart Agroforestry",

The Presiding Member indicated that the practice of Agroforestry is key to the greening of the environment, provision of edible fruits and boosting nature's biodiversity by protecting the wildlife resources of the ecosystem (Schaller et al., 2017). Meanwhile, the concept is a challenge with difficulties in accessing lands and the lack of adequate knowledge on the practice of Climate-Smart Agroforestry. The Presiding Member of the Municipal Assembly who is a male with twenty (20) years working experience at the ANM indicated (2019);

\section{"Lack of adequate knowledge on the Climate-Smart Agroforestry concept do not promote the practising of CSAF.",}

The Abusuapanin specified that Climate-Smart Agroforestry helps in the mitigation of the negatives of climate change, and the trees component are used as timber that is a source of revenue, as Nunoo (2015) indicated. The trees component also serves as windbreaks that are beneficial to the environment. Similarly, unclear tree ownership right constraining the practice of CSAF as well as weak law enforcement on the activities of illegal tree loggers which end up destroying crops on the farmland during harvest without compensation. A male 
royal family's Abusuapanin with ten (10) years' experience with the Goaso Traditional Council in the ANM indicated (2019);

"The law should address ownership tree issues with appropriate enforcement body to prosecute illegal loggers and guarantee farmers' right to own the tree on their farms, this will encourage farmers to practice CSAF. ,

\subsection{Extension workers perceptions on the prospects of CSAF}

According to Williams et al. (2015), the extension services will provide smallholder alternative to select and adapt to the practices of Climate-Smart Agroforestry from their local perspective. In the context of this study, stakeholders in the extension services interviewed included Agriculture Extension Officer in MoFA, District Extension Coordinator in COCOBOD and Assistant District Manager in the Forestry Service Division. The role of the stakeholders in promoting Agroforestry as Climate - Smart Agriculture approach is: The District Extension Coordination indicated that, COCOBOD educate farmers on various platforms to practice Climate-Smart Agroforestry; the Assistant District Manager explained that, Forest Service Division role is towards the promotion of Climate-Smart Agroforestry through the execution of management plans to conserve forest resource, undertake afforestation and reforestation; the Extension Officer explained that MoFA is in charge with the sensitization of farmers on the prospects of Climate-Smart Agroforestry while providing technical services to farmers on the practice of CSAF. Most stakeholders indicated that, Climate-Smart Agroforestry has positive relations with the farmers' socioeconomic development (Nair, 1993), through its potential to conserve soil water, serves as windbreak, providing shade for crops, diversifies the farm produces to reduce crop failure as indicated by Mbow et al. (2014), enhance agro-ecological functions to boost soil fertility for increasing productivity and income while sequestrating carbon. This finding corroborates with Schaller 
et al. (2017). As regards to risk management, most of the stakeholders indicated that ClimateSmart Agroforestry manages farm risk by promoting best practices, a finding similar to Nyasimi et al. (2014). The majority of the stakeholders were of the view that Agroforestry urge reduces inputs usage while enhancing efficiency of farm inputs usage that increases income of the farmer through diversifying the farm produce. This finding agrees with Pretty et al. (2011) that, Agroforestry must reduce unnecessary use of external agricultural inputs such as inorganic fertilisers and the use of agroecological process such as nutrient cycle, which will reduce the adverse effects on the environment while boosting the ecological functions of the natural resources.

The Agricultural Extension Officer at the MoFA indicated CS Agroforestry is the best farming alternative to addressing deforestation by fighting desertification to ensure efficient management of natural resources for sustainable development as claimed by Mbow et al. (2014). The land tenure system is the main factor that does not promote the practice of Climate-Smart Agroforestry since landowners do not allow the cultivation of trees on the lands they rent out to farmers because the long maturity period of the Agroforestry system, this finding corroborates with Rioux (2012). A female Agricultural Extension Officer at MoFA with five (5) years experience in the ANM indicated (2019);

\section{"Climate-Smart Agroforestry is the best alternative to fighting desertification"}

The District Extension Coordinator at Cocoa health and extension division of COCOBOD shows that Climate-Smart Agroforestry protects the forest resource and enhance the resilience of the crops to the increasing effects of extreme events due to climate change. The District coordinator did claim that farmers feel insecure about the growing activities of illegal loggers and the lack of incentives during the practising of Climate-Smart Agroforestry (Table 
6.2). This finding corroborates with Rioux (2012) who claims that land tenure systems, lack of incentives and ownerships issues are significant constraints to the practice of Agroforestry. A male District Extension Coordinator of the cocoa health and extension division with seven (7) years working experience in the ANM explained it as (2019);

"Farmers should be given incentives on adopting Climate-Smart Agroforestry which is environmentally friendly",

The Assistant District Manager at the Forest Service Division of the Ghana Forestry Commission indicated that the tree component of an Agroforestry technology improves soil nutrient, reduce soil erosion and provides shade to shade-tolerant crops such as cocoa while protecting the forest resources to mitigate the effects of climate change on the environment (Table 6.2). A male Assistant District Manager of the Forest Service Division with two (2) years' experience in the ANM indicated (2019);

"The increasing use of farm inputs and the use of poor land use management practices such as slash and burn, without considering its influence on deforestation.",

\subsection{Farmer-based organisation and the private sector's perception of the prospects of CSAF}

The Acting Vice President of the Akrodie Farmers' Association, a Farmer - Based Organization at Akrodie in the Municipal liaises with the Ghana Forestry Commission to educate farmers on the importance of Agroforestry and urge members who are farmers to practice Climate-Smart Agroforestry. The acting vice president indicated that Climate-Smart Agroforestry is beneficiary to the environment by improving soil water management and reduce input usage through its agro-ecological functions to improve soil nutrient, this finding (Table 6.2) was also established by Pretty et al. (2011). In the context of contributing to increasing productivity, increasing income and building the resilience of the farming system, 
the acting president claimed that, Climate-Smart Agroforestry reduces inputs supply and urge the efficient use of inputs and has the potentials to increase crop yield due to its soil nutrient improvement capacity and diversifies the farm produce to reduce crop failure as similarly indicated by Schaller et al., (2017) that, Agroforestry reduces the risk of production failure through diversifying farm products and income sources of the farmers. The acting vice president assessed that the lack of knowledge on the practice CSAF is due to inadequate education from the extension service and lack of credit support for farmers is affecting the adoption of CS Agroforestry that has the potentials to address the challenges born by climate change. A male Acting vice president of the Akrodie Farmers' Association with five (5) years' experience in Akrodie in the ANM indicated (2019);

"The forestry commission should embark on a very high campaign to encourage and support farmers with inputs such as seedlings."

The private sector provides different services towards the promotion of Climate - Smart Agriculture approach, the Samlen Commercial Agency is engaged in consulting and selling of environmentally friendly agrochemicals and other inputs to farmers to enhance and promote Agroforestry practice. Likewise, Gbetibouo (2009) suggested that adaptation measures require capital investment such as agrochemicals and other inputs. The branch manager of Samlen commercial agency indicated that CSAF is beneficial to the environment through its agroecological functions to increase soil nutrient and improve soil water management to increase income generation while alleviating environmental degradation (Table 6.2). Again, Kiptot and Franzel (2011) affirm that Agroforestry prevents environmental degradation. The stakeholder indicated that Agroforestry contributes to the income of the farmers (Kiptot and Franzel, 2011), while reducing the shocks in the farming system exposed by the growing effects of climate change through the efficient extension services and use of farm inputs to increase crop yield and diversify farm inputs to ensure 
market security to farm produces. The branch manager also indicated that Agroforestry provides highly diversified products such as raw materials to the pharmaceutical and agrochemical industry yet challenged by land tenure issues and activities of the illegal loggers in the Municipality, which make farmers reluctant to practice Climate-Smart Agroforestry. To enhance the interest of farmers on the practice of Agroforestry, the forestry commission and other law enforcement agencies should apprehend and prosecute illegal loggers to safe guide farmers and their farms (Table 6.2). A male branch manager of the Samlen commercial agency with five (5) years' experience, a firm engaged in consulting and selling of agrochemicals in the ANM indicated (2019);

"CSAF is challenged by the activities of illegal loggers and land tenure issues. Farmers feel reluctant to engage in tree planting because of the activities of illegal loggers. , 
Table 5: Stakeholders perception on the prospects of practising CSAF

\begin{tabular}{|c|c|c|c|c|c|}
\hline Stakeholders & $\begin{array}{l}\text { Background of } \\
\text { Stakeholders }\end{array}$ & Prospects of CSAF & $\begin{array}{l}\text { Supporting } \\
\text { Literature } \\
\end{array}$ & $\begin{array}{l}\text { Challenges of } \\
\text { CSAF }\end{array}$ & $\begin{array}{l}\text { Supporting } \\
\text { Literature } \\
\end{array}$ \\
\hline \multirow{4}{*}{$\begin{array}{l}\text { Farmer/Consumer } \\
\text { (Goaso, Mim, Kasapin } \\
\text { and Akrodie) }\end{array}$} & \multirow[t]{4}{*}{$\begin{array}{l}\text { Crop producers and } \\
\text { consumers }\end{array}$} & $\begin{array}{l}\text { Ensure market } \\
\text { security }\end{array}$ & $\begin{array}{l}\text { Stringer } e t \\
\text { al., } 2012\end{array}$ & Tree ownership & \multirow[t]{2}{*}{ Rioux, 2012} \\
\hline & & Mitigate CC & $\begin{array}{l}\text { Schaller } e t \\
\text { al., } 2017\end{array}$ & Illegal logging & \\
\hline & & $\begin{array}{l}\text { Agroecological } \\
\text { reason }\end{array}$ & $\begin{array}{l}\text { Pretty et al., } \\
2011\end{array}$ & $\begin{array}{l}\text { Inadequate } \\
\text { technical support }\end{array}$ & $\begin{array}{l}\text { Wollenberg } \\
\text { et al., 2012b }\end{array}$ \\
\hline & & $\begin{array}{l}\text { Reduce production } \\
\text { cost }\end{array}$ & FAO, 2014 & Land tenure & \multirow[t]{2}{*}{$\begin{array}{l}\text { Stringer } e t \\
a l ., 2012\end{array}$} \\
\hline $\begin{array}{l}\text { Municipal Chief } \\
\text { Executive (Asunafo }\end{array}$ & $\begin{array}{l}\text { Head of the ANM, } \\
\text { implementing }\end{array}$ & $\begin{array}{l}\text { Agroecological } \\
\text { functions }\end{array}$ & FAO, 2015a & Illegal loggers & \\
\hline $\begin{array}{l}\text { North Municipal } \\
\text { Assembly) }\end{array}$ & $\begin{array}{l}\text { central government } \\
\text { policies }\end{array}$ & $\begin{array}{l}\text { Diversifies farm } \\
\text { produce }\end{array}$ & $\begin{array}{l}\text { Mbow et al., } \\
2014\end{array}$ & Poor education & $\begin{array}{l}\text { Williams et } \\
\text { al., } 2015\end{array}$ \\
\hline \multirow{3}{*}{$\begin{array}{l}\text { Presiding Member } \\
\text { (Asunafo North } \\
\text { Municipal Assembly) }\end{array}$} & \multirow{3}{*}{$\begin{array}{l}\text { Presiding over } \\
\text { Assembly meetings, } \\
\text { Bye-laws and policy } \\
\text { implementations }\end{array}$} & Wildlife protection & $\begin{array}{l}\text { Leakey et } \\
\text { al., } 2001\end{array}$ & Lack of education & Rioux, 2012 \\
\hline & & Fruits & $\begin{array}{l}\text { Kwesiga et } \\
\text { al., } 2003\end{array}$ & $\begin{array}{l}\text { Inadequate } \\
\text { knowledge }\end{array}$ & $\begin{array}{l}\text { Partey et al., } \\
2018\end{array}$ \\
\hline & & $\begin{array}{l}\text { Soil nutrient } \\
\text { improvement }\end{array}$ & $\begin{array}{l}\text { Pretty et al., } \\
2011\end{array}$ & $\begin{array}{l}\text { Land tenure } \\
\text { system }\end{array}$ & $\begin{array}{l}\text { Pretty et al., } \\
2011\end{array}$ \\
\hline \multirow[t]{3}{*}{$\begin{array}{l}\text { Abusuapanin (Goaso } \\
\text { Traditional Council) }\end{array}$} & \multirow{3}{*}{$\begin{array}{l}\text { Leasing land for } \\
\text { farming, addressing } \\
\text { land tenure disputes, } \\
\text { norms, taboos }\end{array}$} & Mitigate CC & FAO, 2015a & $\begin{array}{l}\text { Poor law } \\
\text { enforcement }\end{array}$ & \\
\hline & & Windbreak, & $\begin{array}{l}\text { Schaller } e t \\
\text { al., } 2017\end{array}$ & Illegal loggers & \\
\hline & & Timber & $\begin{array}{l}\text { Schaller et } \\
\text { al., } 2017\end{array}$ & $\begin{array}{l}\text { Land tenure } \\
\text { system }\end{array}$ & $\begin{array}{l}\text { Stringer } \text { et } \\
\text { al., } 2012\end{array}$ \\
\hline \multirow{2}{*}{$\begin{array}{l}\text { Agricultural Extension } \\
\text { Officer -(Ministry of } \\
\text { Food and Agriculture) }\end{array}$} & \multirow{2}{*}{$\begin{array}{l}\text { Sensitising and } \\
\text { providing technical } \\
\text { services to farmers }\end{array}$} & $\begin{array}{l}\text { Efficient natural } \\
\text { resource use }\end{array}$ & $\begin{array}{l}\text { Schaller et } \\
\text { al., } 2017\end{array}$ & $\begin{array}{l}\text { Land tenure } \\
\text { system }\end{array}$ & Rioux, 2012 \\
\hline & & Soil fertility & $\begin{array}{l}\text { Pretty et al., } \\
2011\end{array}$ & $\begin{array}{l}\text { Landowners do } \\
\text { not allow the plant } \\
\text { of trees }\end{array}$ & Rioux, 2012 \\
\hline \multirow{3}{*}{$\begin{array}{l}\text { District extension } \\
\text { coordinator - } \\
(\mathrm{COCOBOD)}\end{array}$} & \multirow{3}{*}{$\begin{array}{l}\text { Educating and } \\
\text { providing technical } \\
\text { assistance to cocoa } \\
\text { farmers }\end{array}$} & Increase income & WCF, 2017 & $\begin{array}{l}\text { Land tenure } \\
\text { system }\end{array}$ & \multirow[t]{2}{*}{$\begin{array}{l}\text { Williams et } \\
\text { al.,2015 }\end{array}$} \\
\hline & & Inputs efficiency & FAO, 2015 & Illegal logging & \\
\hline & & $\begin{array}{l}\text { It makes farm } \\
\text { resilient to } \mathrm{CC}\end{array}$ & $\begin{array}{l}\text { Mbow et al., } \\
2014\end{array}$ & Lack of incentive & $\begin{array}{l}\text { Gbetibouo, } \\
2009\end{array}$ \\
\hline $\begin{array}{l}\text { Assistant District } \\
\text { Manager (Forest }\end{array}$ & $\begin{array}{l}\text { Conserving forest } \\
\text { resources. Engage in }\end{array}$ & $\begin{array}{l}\text { Soil nutrient } \\
\text { improvement }\end{array}$ & $\begin{array}{l}\text { Pretty et al., } \\
2011\end{array}$ & $\begin{array}{l}\text { Inadequate } \\
\text { knowledge of } \mathrm{CC}\end{array}$ & $\begin{array}{l}\text { Williams et } \\
\text { al., } 2015\end{array}$ \\
\hline \multirow[t]{2}{*}{ Service Division) } & \multirow[t]{2}{*}{$\begin{array}{l}\text { Afforestation and } \\
\text { reforestation }\end{array}$} & Shade & $\begin{array}{l}\text { Pretty et al., } \\
2011\end{array}$ & $\begin{array}{l}\text { Poor land-use } \\
\text { practices }\end{array}$ & Rioux, 2012 \\
\hline & & $\begin{array}{l}\text { Environmental } \\
\text { Conservation }\end{array}$ & FAO, 2015a & & \\
\hline \multirow[t]{2}{*}{$\begin{array}{l}\text { Acting Vice President } \\
\text { - (Akrodie Farmers' } \\
\text { Association) }\end{array}$} & \multirow[t]{2}{*}{$\begin{array}{l}\text { Advocacy and } \\
\text { educating farmers on } \\
\text { best practices }\end{array}$} & Increase crop yield & Nunoo, 2015 & $\begin{array}{l}\text { Inadequate } \\
\text { knowledge }\end{array}$ & Rioux, 2012 \\
\hline & & Diversifies produce & $\begin{array}{l}\text { Schaller et } \\
\text { al., } 2017\end{array}$ & $\begin{array}{l}\text { Lack of credit } \\
\text { facility }\end{array}$ & $\begin{array}{l}\text { Gbetibouo, } \\
2009\end{array}$ \\
\hline \multirow{2}{*}{$\begin{array}{l}\text { Branch Manager - } \\
\text { (Samlen Commercial } \\
\text { Agency) }\end{array}$} & \multirow{2}{*}{$\begin{array}{l}\text { Consulting and } \\
\text { selling of } \\
\text { agrochemicals and } \\
\text { other inputs }\end{array}$} & $\begin{array}{l}\text { Carbon } \\
\text { sequestration }\end{array}$ & $\begin{array}{l}\text { Pretty et al., } \\
2011\end{array}$ & $\begin{array}{l}\text { Illegal logging } \\
\text { activities }\end{array}$ & \\
\hline & & $\begin{array}{l}\text { Mitigate climate } \\
\text { change } \\
\text { Increase } \\
\text { productivity } \\
\text { Medicinal plant }\end{array}$ & $\begin{array}{l}\text { Schaller } \text { et } \\
\text { al., } 2017 \\
\text { Pretty et al., } \\
2011\end{array}$ & $\begin{array}{l}\text { Inadequate } \\
\text { extension service } \\
\text { Poor law } \\
\text { enforcement }\end{array}$ & $\begin{array}{l}\text { Harvey et al., } \\
2014\end{array}$ \\
\hline
\end{tabular}

Source: Author's field survey, 2019 


\subsection{SUMMARY, CONCLUSION AND RECOMMENDATIONS}

This chapter presents an overview of the study including summary of findings in section 4.1, conclusion of the study in section 4.2 , whereas section 4.3 presents the recommendations of the survey among key stakeholders on the prospects of CSAF in the Asunafo North Municipal in Ghana.

\subsection{Summary of findings}

The summary of the conclusion of the research objectives includes; stakeholders' perception on the prospects including challenges of practising Climate-Smart Agroforestry in the Asunafo North Municipal Assembly in the Ahafo Region in Ghana. The majority of the respondents indicated the use of Agroforestry as Climate - Smart Agriculture Technology could best help adapt to the threatening effects of climate change in the agriculture sector; most are willing to practice Agroforestry due to its agro-ecological benefits and the ability of trees to serve as windbreak on farmlands. Most mentioned that Climate-Smart Agroforestry ensures a better market system to farm produce. The majority indicated cost of production decreases during the practice of Agroforestry and the majority revealed that, the practice of Agroforestry has positive relation to the farmer's socioeconomic development with benefits such as agroecological functions, soil water improvement and the soil nutrient management which are significant to the farmland geared towards enhancing the production level while boosting the income of the farmer, and also CS Agroforestry intensifies diversification of farm products to manage risk and enhance resilience of the farming system

\subsection{Conclusion}

Agroforestry as Climate-Smart Agriculture Technology has the potential to increase productivity and income of the farmers, build resilience for the agricultural farming system and remove or reduce greenhouse gases. The study concludes that Agroforestry has the 
prospects to achieve the three CSA objectives to enhance food security and reduce poverty while protecting the environment. Based on the findings, the study concludes that CSAF can help best adapt to climate change due to its agroecological functions, ability to reduce production cost by lessening inputs usage on the farm, CSAF improves soil water management, enhance risk management while ensuring market security for farm produce through diversification. Further, the study concludes the practice of Agroforestry has positive relation to the farmer's socioeconomic development with benefits such as agroecological functions, soil water improvement and the soil nutrient management which are significant to the farmland geared towards enhancing the production level while boosting the income of the farmer, and CS Agroforestry intensifies diversification of farm products to manage risk and enhance resilience of the farming system.

\subsection{Recommendation}

There is the need for better understanding of the contribution Climate-Smart Agroforestry concept to adapt and mitigate the effects of climate change and how climate change affects the growth of crops while providing incentives to farmers for protecting the environment and enhancing the ecosystem-based of the natural resources. This will boost farmers' interest to practice Climate-Smart Agroforestry. This will also help farmers to join in the adoption and adaptation of Agroforestry. The study further recommends the need for development of methods and approaches scaling Agroforestry technologies to attain landscape-level impacts. This will improve farmers' knowledge and understanding of the benefits of practising Agroforestry. 


\section{REFERENCES}

Almeida, F., Faria, D., and Queiros, A. (2017). Strengths and limitations of qualitative and quantitative research methods. European Journal of Education Studies. Volume 3. 369387

Ashley, H., Tamargo, A., Bailey, C., \& Kim, Y. (2015). Assessment of Climate Change Impacts on Cocoa Production and Approaches to Adaptation and Mitigation: A Contextual View of Ghana and Costa Rica. International Development Studies Capstone. World Cocoa Foundation

Asunafo North Municipal Assembly (ANMA) (2018). Composite budget for 2018-2021. Programme based on estimates for 2018. Republic of Ghana.

Biesbroek, G. R., Swart, R.J. \& van der Knaap, W. G.M. (2009). The mitigation-adaptation dichotomy and the role of spatial planning. Habitat Int., 33, 230-237.

Boko, M., Niang I., Nyong, A., Vogel, C., Githeko, A., Medany, M., Osman-Elasha, B., Tabo, R. and Yanda, P. (2007). Africa Climate Change 2007: Impacts, Adaptation and Vulnerability. Contribution of Working Group II to the Fourth Assessment Report of the Intergovernmental Panel on Climate Change, Parry, M. L., Canziani, O. F., Palutikof, J. P., van der Linden, P. J. and Hanson, C. E. (eds). Cambridge University Press. Cambridge UK. pp. $433-467$.

Braimoh, A., Emenanjo, I., Rawlins, M. A., Heumesser, C., Zhao, Y. (2016). Climate-Smart Agriculture Indicators (English). Washington, D. C. World Bank G

FAO (2014a). Climate-Smart Agriculture: What is it? Why is it needed? http://www.fao.org/3/ai4226e.pdf

Gbetibouo, G. A. (2009). Understanding farmerse perceptions and adaptations to climate change and variability. The case of the Limpopo basin, South Africa. IFPRI Discussion Paper No. 00849

Ghana Statistical Service (2010). Ghana Population and Housing Census. Government of Ghana: Accra, Ghana.

Guernier, V., Hochberg, M. E., Guegan, J. F. (2004). Ecology drives the worldwide distribution of human diseases. PLOS Biology. Oxford. 2(6): pp. 740 - 746

Harvey, C. A., Chac'on, M., Donatti, C. I., Garen, E., Hannah, L., Andrade, A., Bede, L., Brown, D., Calle, A., Char'a, J., Clement, C., Gray, E., Hoang, H. M., Minang, P., Rodr'iguez, A. M., Seeberg-Elverfeldt, C., Semroc, B., Shames, S., Smukler, S., Somarrib, E., Emmanuel Torquebiau, E., van Etten, J., \& Wollenberg, E. (2014). Climate-Smart Landscapes: Opportunities and Challenges for Integrating Adaptation and Mitigation in Tropical Agriculture. Conservation Letters 00, 1-14. Wiley Periodicals, Inc.

Harrus, S., and Baneth, G. (2005). Drivers for the emergence and reemergence of vectorborne protozoal and rickettsial organisms. International journal for parasitology. 35: pp. 1309 - 1318. 
Hauswirth, D., Pham, T. S., Nicetic, O. et al. (eds) (2012). Conservation Agriculture and Sustainable Upland Livelihoods. Innovations for, with and by Farmers to Adapt to Local and Global Changes. Proceedings of the 3rd International Conference on Conservation Agriculture in Southeast Asia. Held in Hanoi, Vietnam, 10th-15th December 2012. CIRAD, Montpellier, France; NOMAFSI, Phu Tho, Viet Nam; University of Queensland, Brisbane, Australia. 372 p.

Kiptot, E. and Franzel, S. (2011). Gender and agroforestry in Africa: are women participating? ICRAF Occasional Paper No. 13. Nairobi: World Agroforestry Centre.

Läderach, P., Eitzinger A., Martinez, A., Castro, N. (2011). Predicting the Impact of Climate Change on the Cocoa Growing Regions in Ghana and Cote d'Ivoire. Final Report. P 35.

Lahive, F., Hadley, P. \& Daymond, A. J. (2019). The physiological responses of cacao to the environment and the implications for climate change resilience. A review. Agronomy for Sustainable Development 39: 5. https://doi.org/10.1007/s13593-018-0552-0

Matata, J. B.W., Anandajayasekarani, A., Kiriro, T. N., Wandera, E. O. \& Dixon J. (2001). Farming systems approach to technology development and the transfer: FARMESA, Harare, Zimbabwe. 420pp.

Mattison, E. H. A. \& Norris, K. (2005). Bridging the gaps between agricultural policy, landuse and biodiversity. Trends Ecol. Vol., 20, 610-616.

Mbow, C., Smith, P., Skole, D., Duguma, L., \& Bustamante, M. (2014). Achieving mitigation and adaptation to climate change through sustainable agroforestry practices in Africa. Current Opinion in Environmental Sustainability, 6, 8-14.

Nair, P. K. R. (1993). An introduction to agroforestry. Kluwer Academic publisher, Dordrecht, Netherland.

Nunoo, I. (2015). Financial viability of cocoa agroforestry systems in Ghana: the case of Sefwi Wiawso district. MPhil thesis. KNUST, Ghana.

Nyasimi, M., Kimeli, P., Sayula G., Radeny, M., Kinyangi, J. and Mungai, C. (2017) Adoption and Dissemination Pathways for Climate-Smart Agriculture Technologies and Practices for Climate-Resilient Livelihoods in Lushoto, Northeast Tanzania. Climate, 5, 63. MDPI, Basel, Switzerland. www.mdpi.com/journal/climate

Nyasimi, M., Amwata, D., Hove, L., Kinyangi, J., and Wamukoya, G. (2014). Evidence of Impact: Climate-Smart Agriculture in Africa. CCAFS Working Paper no. 86. CGIAR Research Program on Climate Change, Agriculture and Food Security (CCAFS). Copenhagen, Denmark. Available online at: www.ccafs.cgiar.org

Partey, S. T., Zougmoré, B. R., Ouédraogo, M., and Campbell, B. M. (2018). Developing Climate - Smart Agriculture to face Climate Variability in West Africa: Challenges and Lessons Learnt. Journal Cleaner Production 187, 285 - 295.

Partey, S. T., Zougmoré, B. R., Ouédraogo, M., and Thevathasan, N. V. (2017). Why Promote Improved Fallows as a Climate-Smart Agroforestry Technology in SubSaharan Africa? Sustainability, 9, 1887. MDPI, Basel, Switzerland. 
Pretty, J., Toulmin, C., and Wouldiams, S. (2011). Sustainable intensification in African agriculture. International journal of agricultural sustainability, 9(1): 5-24.

Rioux, J. (2012) Opportunities and Challenges of Promoting Agroforestry for Climate Change Mitigation: A Case-Study of the Mitigation of Climate Change in Agriculture (MICCA) Pilot Project in Tanzania. FAO Regional Office for Africa. Nature and Faune. Volume 26, Issue 2.

Schaller, M., Barth, E., Blies, D., Röhrig, F., Schümmelfeder, M. (2017). Climate Smart Agriculture (CSA): Climate Smart Agroforestry. International Center for Tropical Agriculture. The Center for Rural Development (SLE), Berlin. 4p. https://hdl.handle.net/0568/82727

Stringer, L. C., Dougill, A. J., Spracklen, D. V., et al. (2012). Challenges and opportunities in linking carbon sequestration, livelihoods and ecosystem service provision in drylands. Environ. Sci. Policy, 19-20, 121-135.

Toppo, P. and Raj, A. (2018). Role of agroforestry in climate change mitigation. Journal of pharmacognosy and Phytochemistry. www.phytojournal.com

Williams, O. T., Mul, M., Cofie, O., Kinyangi, J., Zougmore, R., Wamukoya, G., Nyasimi, M., Mapfumo, P., Speranza, I. C., Amwata, D., Frid-Nielsen, S., Partey, S., Girvetz, E., Rosenstock, T., Campbell, B. M. (2015). Climate Smart Agriculture in the African Context. Background paper. Feeding Africa conference 21 - 23 October, 2015 